\title{
Polymeric micelles and molecular modeling applied to the development of radiopharmaceuticals
}

\author{
Sibila Roberta Marques Grallert ${ }^{1, *}$, Carlota de Oliveira Rangel-Yagui ${ }^{2}$, \\ Kerly Fernanda Mesquita Pasqualoto ${ }^{3}$, Leoberto Costa Tavares ${ }^{1}$
}

\begin{abstract}
${ }^{l}$ Department of Biochemical and Pharmaceutical Technology, Faculty of Pharmaceutical Sciences, University of São Paulo, ${ }^{2}$ Department of Pharmacy, Faculty of Pharmaceutical Sciences, University of São Paulo, ${ }^{3}$ Laboratory of Biochemical and Biophysics, Butantan Institute, São Paulo
\end{abstract}

\begin{abstract}
Micelles composed of amphiphilic copolymers linked to a radioactive element are used in nuclear medicine predominantly as a diagnostic application. A relevant advantage of polymeric micelles in aqueous solution is their resulting particle size, which can vary from 10 to $100 \mathrm{~nm}$ in diameter. In this review, polymeric micelles labeled with radioisotopes including technetium $\left({ }^{99 \mathrm{~m}} \mathrm{Tc}\right)$ and indium $\left({ }^{111} \mathrm{In}\right)$, and their clinical applications for several diagnostic techniques, such as single photon emission computed tomography (SPECT), gamma-scintigraphy, and nuclear magnetic resonance (NMR), were discussed. Also, micelle use primarily for the diagnosis of lymphatic ducts and sentinel lymph nodes received special attention. Notably, the employment of these diagnostic techniques can be considered a significant tool for functionally exploring body systems as well as investigating molecular pathways involved in the disease process. The use of molecular modeling methodologies and computer-aided drug design strategies can also yield valuable information for the rational design and development of novel radiopharmaceuticals.
\end{abstract}

Uniterms: Radiopharmaceuticals/development. Polymeric micelles/diagnostic application. Radioisotopes. Imaging diagnostic agents. Diagnostic techniques.

Micelas poliméricas compostas de copolímeros ligadas a um elemento radioativo são utilizadas em Medicina Nuclear com aplicação predominantemente diagnóstica. A vantagem relevante da utilização de micelas poliméricas em solução aquosa é o tamanho de suas partículas, as quais podem variar de 10 a $100 \mathrm{~nm}$ de diâmetro. Neste trabalho de revisão são apresentadas micelas poliméricas marcadas com radioisotopos, como tecnécio-99m $\left({ }^{99 m} \mathrm{Tc}\right)$ e índio-111 ( $\left.{ }^{111} \mathrm{In}\right)$, assim como suas aplicações clínicas em técnicas de diagnóstico como Tomografia por emissão de Fóton Único (Single photon Emission Computed Tomography - SPECT), cintilografia, e Ressonância Magnética Nuclear (RMN). Neste contexto, sua aplicação em diagnóstico de sistema linfático e linfonodo sentinela recebe atenção especial. O emprego de técnicas de diagnóstico pode ser considerado uma ferramenta importante para a exploração de sistemas no organismo humano assim como para a investigação de caminhos moleculares envolvidos nos processos de diversas doenças. O uso de metodologias de modelagem molecular e estratégias de desenvolvimento de fármacos assistidas computacionalmente também pode fornecer informações valiosas para o planejamento e o desenvolvimento racional de novos radiofármacos.

Unitermos: Radiofármacos/desenvolvimento. Micelas poliméricas/aplicação diagnóstica. Radioisótopos. Agentes para imagens em diagnóstico. Técnicas de diagnóstico.

\section{INTRODUCTION}

In recent decades, technological and scientific ad-

\footnotetext{
*Correspondence: S. R. M. Grallert. Departamento de Tecnologia Bioquímico-Farmacêutica, Faculdade de Ciências Farmacêuticas, Universidade de São Paulo. Av. Prof. Lineu Prestes, n.580 - 05508-000 - São Paulo - SP, Brasil. E-mail: sgrallert@uol.com.br, sgrallert@usp.br
}

vances in molecular imaging have allowed the identification and characterization of the components, processes, dynamics and therapy of diseases at a molecular level. The use of new molecules, radiopharmaceuticals or contrast agents, allied to traditional imaging tools, has enabled visualization of tissular events and disclosure of the specific molecular targets in the body which are 
responses during disease progression (Pan et al., 2009; Wong, Kim, 2009).

The fields of diagnostic medicine by imaging methods include the use of positron-emitting (particulate $\beta+$ radiation) and gamma-emitting ( $\gamma$ radiation) radioactive materials in techniques such as computed tomography (CT) associated to positron emission tomography (PET) and single photon emission computed tomography (SPECT), or the use of contrast agents in CT, magnetic resonance imaging (MRI), and ultrasonography (U.S.) (Hamoudeh et al., 2008).

In all of the above-mentioned methods, clinical diagnosis requires a certain intensity of signal emitted from the area of interest so that the difference between the structure under observation and the surrounding tissues can be recorded. In this context, radiopharmaceuticals and contrast agents are employed for their ability to adsorb these signals (radiation) more strongly than neighboring tissues (Hamoudeh et al., 2008).

To achieve the necessary concentration of a radiopharmaceutical at the desired site, several carriers such as nanoparticles, liposomes, and microspheres, for example, have been proposed (Grallert, 2006; Torchilin, 1999). Micelles, which are colloidal particles formed by amphiphilic moieties, number among the carriers exploited, particularly due to their physicochemical properties of easy handling and suitable pharmacokinetic characteristics (Kwon, Kataoba, 1995; Lasik, 1992).

In this sense, the particle size, charge and surface properties of micelles can be modified by adding new compounds to the mixture of amphiphilic agents or by changing the preparation method in order to target distinct types of in vivo release profiles. Some micelles, upon exposure of their outer surface to the aqueous environment. have low reactivity to blood and tissue components, enabling them to remain in circulation for long periods of time without being recognized by proteins and/ or phagocytic cells. This longevity is a highly relevant feature of micelles as drug carriers since it allows their gradual accumulation in specific clinically important areas (Torchilin, 2002).

However, there is growing interest in nuclear medicine images of the lymphatic system, also known as lymphoscintigraphy, due to a recent histopathological validation of the sentinel lymph node (SLN) concept in patients with surface cancers such as malignant melanoma and breast cancer (Kowalsky, Falen, 2004; Wilhelm, Mijnhout, Franssen, 1999). In the latter case, the SLN biopsy procedure has gradually replaced the axillary lymph node dissection technique (Sener, 2004; Vera, Wallace, Hoh, 2001). Moreover, the SLN concept has also been applied to the treatment of endometrial cancer in an effort to avoid complete systematic lymphadenectomy whenever possible (Nikura et al., 2004).

In general, lymph nodes are an early site for cancer spread (metastasis) and local spread of infectious diseases such as acquired immunodeficiency syndrome (AIDS). The SLN in particular, is the first lymph node subject to direct drainage from the primary lesion site of the tumor, being more likely to contain metastatic tumor cells than other lymph nodes in the same region. Usually, the prognostic significantly improves when cancer cells are not found in the SLN by pathological examination (Kowalsky, Falen, 2004; Goins, Phillips, 2001).

Radiopharmaceuticals such as technetium $\left({ }^{99 \mathrm{~m}} \mathrm{Tc}\right)$ sulfur colloid, ${ }^{99 \mathrm{~m}} \mathrm{Tc}$ filtered sulfur colloid, ${ }^{99 \mathrm{~m} \mathrm{Tc}-a l b u m i n}$ colloid, ${ }^{99 \mathrm{~m}} \mathrm{Tc}$-antimony trisulfide colloid, and ${ }^{99 \mathrm{~m}} \mathrm{Tc}-$ human serum albumin, are currently used for detecting SLNs (Sener et al., 2004; Vera, Wallace, Hoh, 2001; Nieweg et al., 1999). The colloidal forms, especially ${ }^{99 \mathrm{~m}} \mathrm{Tc}$ filtered sulfur colloid, have slower rate of clearance from the site of injection. Thus, the scattering of radiation from the application site can mask the SLN, which is often located only a few inches away. Radiopharmaceuticals without affinity for lymph nodes, such as albumin colloid labeled with ${ }^{99 \mathrm{~m}} \mathrm{Tc}$, can circulate through the lymphatic system over long periods, impairing the identification of the SLN (Vera, Wallace, Hoh, 2001).

In this review, distinct preparation methods of polymeric micelles, and their applications as radiopharmaceuticals, are discussed, outlining the mapping of the lymphatic system, SLN, and tumors. Additionally, molecular modeling and computer-aided drug design (CADD) strategies for the rational design of radiopharmaceuticals are focused.

\section{NANOTECHNOLOGY}

Nanotechnology is a field of research at a crossroads with biology, chemistry, physics, engineering, and medicine. According to the National Nanotechnology Initiative (NNI; http://www.nano.gov), nanotechnology refers to the understanding and control of matter at dimensions between approximately 1 and $100 \mathrm{~nm}$ (nanoscale), where unique phenomena enable novel applications. Unusual physical, chemical, and biological properties can emerge in materials at the nanoscale. These properties may differ in important ways compared to the properties of bulk materials and single atoms or molecules. Considering this size range in perspective, a small molecule, a virus, a bacterium, and the cross section of a human hair are around $1 \mathrm{~nm}, 100 \mathrm{~nm}, 1000 \mathrm{~nm}$ and 100,000 nm, respectively 
(Hamoudeh et al., 2008; Alexis et al., 2008).

Nanotechnology generally refers to structures that are up to several hundred nanometers in size, and are developed by top-down or bottom-up engineering of individual components based on a rational design. The resulting nanomaterials may have functional properties that are conferred through the precise assembly of individual components but not by the individual components alone. Nanomaterials have a large surface area to volume ratio and their physicochemical properties, such as friction and interaction with other molecules, are distinct from equivalent materials at a larger scale (Alexis et al., 2008; Ferrari, 2005).

The most common application of nanotechnology in medicine has been in the development of both new therapeutic agents and distinct imaging modalities for diagnosis. In the first case, nanocarriers can mainly improve solubility, the pharmacokinetic profile of drugs and provide site-specificity. For diagnostic imaging, the main contribution is site-specificity. Examples of nanocarrier systems include polymeric micelles, dendrimers, nanocapsules, liposomes, nanoparticles based on nucleic acid, and viral nanoparticles (Ferrari, 2005).

The nanocarrier or drug delivery systems have the potential to improve the therapeutic index of currently used drugs, and may increase their efficacy, reduce their toxicity or enhance their bioavailability. They can also aid the solubility and stability of drugs, allowing the development of novel chemical entities which were formerly rejected in pre-clinical or clinical phases due to their inappropriate pharmacokinetics or biochemical profile (Wong, Kim, 2009; Rangel-Yagui, 2007). Moreover, nanocarrier systems can facilitate the development of multifunctional polymeric systems for targeted drug delivery (Nasongkla et al., 2006), combination therapy (Larina et al., 2005), or systems for use in therapy or diagnosis (Alexis et al., 2008).

The first nanocarrier system was a liposome developed approximately 40 years ago (Bangham, Standish, Watkins, 1965), also reported by Torchilin (2005). The last two decades, however, has seen a significant improvement in the development of colloidal carriers in the nanoscale size range that have distinct chemical and physicochemical properties for application as drug vectors. More recently, the U.S. Food and Drug Administration (FDA) approved the first generation of nanoparticle formulations such as Feridex (Wang, Hussain, Krestin, 2001) for diagnostic applications and Abraxane (Green et al., 2003) and Doxil (Ellerhorst et al., 1999) for cancer therapy.

Polymeric micelles represent the most effective class of nanocarrier systems for diagnostic applications and tumor chemotherapy (Alexis et al, 2008). Several types of micelles have been proposed as delivery vehicles for drugs including paclitaxel (Zhang, Jackson, Burt, 1996) and doxorubicin (Yokoyama et al., 1990) in cancer therapy as well as for diagnostic agents, such as a complex of gadolinium with a chelating agent (diethylenetriaminepenta-acetic acid, Gd-DTPA) (Trubetskoy et al., 1996). In addition, polymeric micelles have also been used in radiopharmacy applications to aid the diagnostic procedure for lymphatic pathways and for detecting the SLN (Hamoudeh et al., 2008).

In this context, a recent advance in pharmaceutical technology applied to radiopharmacy involves the search for new carrier agents on the nanoscale $\left(10^{-9} \mathrm{~m}\right)$ such as liposomes, and on the microscale $\left(10^{-6} \mathrm{~m}\right)$, such as polymeric microcapsules. Nanomedicine, which is the medical application of nanotechnology, is set to exploit this information for developing new approaches in molecular diagnosis, tumor imaging and targeted therapies (Hamoudeh et al., 2008; Alexis et al., 2008).

\section{PHYSICOCHEMICAL PROPERTIES OF POLYMERIC MICELLES}

Surfactants are amphiphilic molecules composed of a hydrophilic or polar moiety known as the "head", and a hydrophobic or nonpolar moiety known as the "tail" (Israelachvili, 1992). Surfactants in aqueous solution can display distinct kinds of behavior depending on their concentration. When surfactant molecules are dissolved in aqueous solution at concentrations above the critical micelle concentration (CMC), they spontaneously form aggregates known as micelles, in which the hydrophilic head regions are in contact with the surrounding solvent (water), sequestering the hydrophobic tail regions in the micelle centre thus minimizing their contact with water (Torchilin, 2007; Trubetskoy, 1999; Chevalier, Zemb, 1990).

The formation of micelles in water results from a delicate balance of intermolecular forces, including van der Waals, electrostatic, steric, hydrophobic, and hydrogen bonding interactions (Rangel-Yagui, Pessoa-Jr, Tavares, 2005; Israelachvili, 1992; Tanford, 1980).

Micellar systems have particular significance in pharmacy given their ability to increase solubility of sparingly soluble drugs and to improve their bioavailability, as well as to reduce toxicity and other harmful side effects, enhance permeability through biological barriers, and provide significant changes in biodistribution. The lower the CMC value of a given surfactant, the more stable are its micelles. This is especially important from a pharma- 
cological point of view, since upon dilution with a large volume of blood, considering intravenous administration, only micelles of surfactants with low CMC value remain, while micelles from surfactants with high $\mathrm{CMC}$ value may dissociate into monomers and their content precipitate in the blood (Rangel-Yagui, Pessoa-Jr, Tavares, 2005). The use of certain amphiphilic molecules such as polymeric types may also increase the plasma half-life of micelles upon intravenous administration. Moreover, specific ligands can be chemically attached to the micellar surface, and the drug release at the site of action, directly from within the micelles to the target (tissue/cells), should provide an increase in drug effectiveness, whereas the stability of micelles can also contribute to a reduction in toxicity (Torchilin, 2006, 2007).

According to Kabanov et al. (1992), the ideal selfassembling drug delivery system should spontaneously form from drug molecules, carrier components and targeting moieties, and should have the following specific properties: (i) aggregate size of around $10 \mathrm{~nm}$ in order to enable them to penetrate various tissues and even cells; (ii) be stable in vivo for a sufficiently long period of time without causing any undesirable biological reactions; (iii) release the drug upon contact with target tissues/cells; and, (iv) the components of the carrier (loader or surfactant molecules) should be easily removed from the body when the therapeutic function has been achieved.

The use of polymeric micelles as a drug delivery system deserves special attention. Polymeric micelles are formed from copolymers consisting of both hydrophilic and hydrophobic monomer units (Torchilin, 2002). Hence, unlike homopolymers, which are formed by identical monomer units, copolymers present two kinds of monomers differing in solubility. In Figure 1, a schematic representation of the mechanism of polymeric micelle formation is shown. Copolymers such as $\mathrm{AB}$ or $\mathrm{ABA}$ can spontaneously assemble into a number of supramolecular structures of different morphology in aqueous solution. Also, copolymers such as AB (amphiphilic block copolymers) whose length of the hydrophilic block exceeds the length of the hydrophobic block, generally form spherical micelles in aqueous medium (Trubetskoy, 1999). The micellar core corresponds to hydrophobic blocks whereas the shell region, which is in contact with the aqueous solution, consists of hydrophilic blocks (Kwon, Kataoka, 1995).

Micelles formed from copolymers such as AB and ABA are of greater interest pharmacologically. The hydrophilic group commonly consists of polyethylene oxide (PEO, also known as polyethylene glycol, PEG) chains, a polymer that is highly soluble in water (Kwon, 1998). The main advantage of copolymers containing PEO head groups is their low toxicity (Magnusson, Olson, Nyberg, 1986). Moreover, the PEO coating efficiently prevents opsonization and subsequent recognition by macrophages of the reticuloendothelial system (RES), allowing the micelles to circulate longer and deliver drugs more effectively to the desired sites (Rapoport, 2007; Soo et al., 2002; Trubetskoy, Torchilin, 1995).

The low CMC values associated with the formation of polymeric micelles confer high pharmacokinetic stability. Micelles having high CMC values when subject to extreme dilution in circulating blood can dissociate into monomers before reaching the target site. Conversely, the slow dissociation of kinetically stable polymeric micelles allows them to retain their integrity and drug content in blood circulation above or even below the CMC for some time, reaching the target site before decaying into monomers. (Rangel-Yagui, Pessoa Junior, Tavares, 2005; Torchilin, 2006).
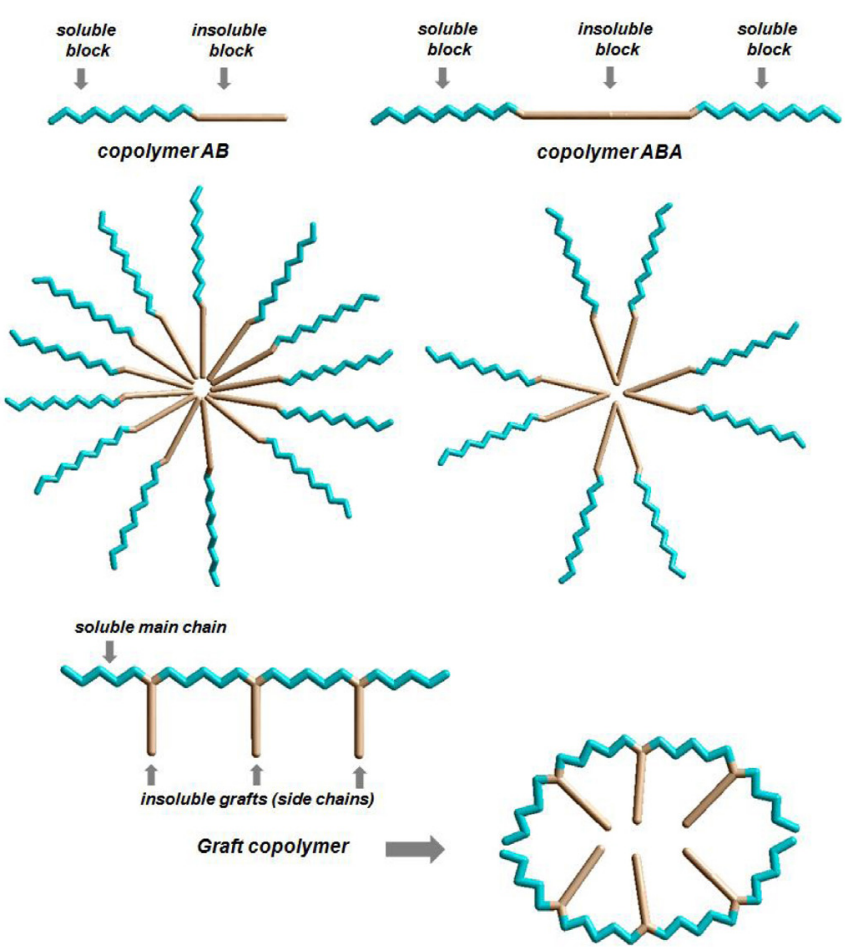

FIGURE 1 - Formation of polymeric micelles from different types of amphiphilic block copolymers (Adapted from: Torchilin, 2001).

As previously mentioned, a very important property of polymeric micelles is their size, typically from 10 to $100 \mathrm{~nm}$, occupying the gap between drug carriers such as individual macromolecules (albumin, dextran, and antibodies) with a size less than $10 \mathrm{~nm}$, and nanocarriers such as liposomes and microcapsules measuring $100 \mathrm{~nm}$ or larger (Rangel-Yagui, Pessoa Junior, Tavares, 2005; 
Trubetskoy, 1999). This is relevant for selected drug administration routes such as percutaneous lymphatic delivery, or for extravasation into solid tumors. From a practical standpoint, micellar preparations are easy to prepare, handle, and sterilize by filtration, mainly due to their small size (Trubetskoy, 1999).

\section{CLINICAL APPLICATIONS}

Clinical applications of polymeric micelles as carriers of radiopharmaceuticals and diagnostic (contrast) agents are based upon the unique properties of these supramolecular assemblies in aqueous solution. Radiopharmaceuticals and diagnostic agents serve to delineate body systems, organs and tissues on the images upon oral or parenteral administration. Most commonly used radiopharmaceuticals for two important imaging modalities present chelated radioactive metals in their composition, such as indium $\left({ }^{111} \mathrm{In}\right)$ or technecium $\left({ }^{99 \mathrm{~m}} \mathrm{Tc}\right)$ for scintigraphy, and organic iodine $\left({ }^{123} \mathrm{I}\right)$ for CT. Conversely, contrast agents, which are generally used in MRI, do not have a radioactive element in their structure, but instead contain chelated paramagnetic metals, such as gadolinium (Gd) (Hamoudeh et al., 2008; Torchilin, 1999; Trubetskoy, 1999).

Contrast agents, also referred to as imaging enhancers, were included in this review of radiopharmaceuticals given their relevance in terms of clinical application, as diagnostic agents, and in academic research as a basis for developing novel non-invasive cellular imaging techniques, for example.

The overwhelming majority of radiopharmaceuticals currently used in clinical medicine are low-molecular weight compounds having the above-mentioned chemical moieties. However, there are some applications in clinical imaging which require the use of high-molecular weight radiopharmaceuticals or particulate contrast agents. They may be needed for example in order to overcome the inconvenience of rapid disappearance of low-molecular weight radiopharmaceuticals into interstitial space, impairing the proper delineation of the vasculature or lymphatics during surgical procedures aided by imaging agents. The three most obvious examples of the use of particulate radiopharmaceuticals are blood pool imaging by longcirculating particulate carriers, tumor accumulation as a result of circulation longevity, and accumulation of particulates in lymph nodes after subcutaneous administration (Alexis et al., 2008, Torchilin, 1999; Trubetskoy, 1999). Most of these applications have clinical significance during detection and staging of distinct types of human cancers (Hamoudeh et al., 2008), as well as for diagnosing certain heart conditions (Trubetskoy, 1999).
The use of polymeric micelles as carriers of radiopharmaceuticals and diagnostic agents can yield great clinical benefits in all three major imaging modalities (scintigraphy, CT, MRI). For each of these specific applications, certain requirements related to the diagnostic agent should be taken into account. The most important is certainly the presence of a protective polymeric layer on the particles to prevent interaction with RES cells. In this case, the size of resulting particulates is also of prime importance (Trubetskoy, 1999).

\section{POLYMERIC MICELLES CONTAINING AMPHIPHILIC POLYCHELATORS AS DIAGNOSTIC AGENTS}

As previously mentioned, clinical diagnostic imaging requires that a certain intensity of signal (irradiation) from an area of interest is achieved in order to differentiate structures under observation from surrounding tissues. The efficacy of micelles as radiopharmaceuticals or contrast agents could be improved by increasing the quantity of carrier-associated reporter metal (such as ${ }^{111} \mathrm{In}$ or Gd), thus enhancing signal intensity (Torchilin, 1999).

Torchilin and Trubetskoy (1994) tried to tackle this issue by using so-called amphiphilic chelating polymers. These authors experimentally designed a new family of soluble single-terminus modified polymers containing multiple chelating groups suitable for incorporation into liposomes and micelles. The approach was based upon the use of carbobenzoxy (CBZ)-protected polylysine (PL) with a free terminal amino-group, which is derivatized into a reactive form with subsequent deprotection and incorporation of diethylenetriaminepentaacetic acid (DTPA) residues, and was initially suggested as a heavy metal label in proteins and antibodies (Torchilin, 1999; Slinkin, Kilbanov, Torchilin, 1992).

Considering the PL N-terminus modification chemistry, the pathway for the synthesis of amphiphilic polychelator N, $\alpha$-(DTPA-polylysyl)glutaryl phosphatidyl ethanolamine (DTPA-PL-NGPE) was developed. DTPA-PL-NGPE easily incorporates into the micelle and increases the number of metal atoms attached to a single lipid anchor. Thus, the number of bound reporter metal atoms per single carrier particle can be increased (Torchilin, 1999).

Micelles formed by self-assembled amphiphilic polymers such as PEO- phosphatidyl ethanolamine (PEO$\mathrm{PE})$ can also be labeled with amphiphilic PL-based chelates carrying diagnostically important metal ions, such as ${ }^{111} \mathrm{In}$ and Gd (Trubetskoy, Torchilin, 1996), and the final preparations are relatively stable in vivo. In case of 
the MRI modality, it is especially important that chelated metal atoms are directly exposed to the water environment, which improves the relaxivity of the paramagnetic ions and leads to the corresponding enhancement of the vesicle contrast properties (Torchilin, 1999).

The presence of PEO in the vicinity of paramagnetic atoms helps reduce the total dose of an administrated metal due to the increase in the relaxivity of the particulate. Additionally, upon subcutaneous administration, micelles rapidly move via the lymphatic pathway, mostly staying within lymph fluid rather than accumulating in the nodal macrophages because of the protective effect of the surface PEG fragments (Torchilin, 1999).

\section{POLYMERIC MICELLES LABELED WITH PARAMAGNETIC METALS FOR MRI}

The delivery of therapeutics by micelles is a welldeveloped and evolved field (see refs Rangel-Yagui, Pessoa Junior, Tavares, 2007; Rangel-Yagui, Pessoa Junior, Tavares, 2005; Kwon, 1995 for examples). Besides the practical value for diagnosis itself, this area is relevant for the visualization of the exact sites of drug carrier deposition within the body with extraordinary anatomical resolution (Torchilin, 1999).

Chelated paramagnetic metal moieties ( $\mathrm{Gd}, \mathrm{Mn}$ or Dy aqueous ions) represent the major interest for designing contrast agents applied to diagnosis using MRI (Trubetskoy et al., 1996). Mixed micelles obtained from monoolein and taurocholate with Mn-mesoproporphyrin, for example, seem to be a potential oral hepatobiliary contrast agent for MRI (Schmeidl et al., 1995). Chelated metal ions frequently have a hydrophilic character. The complex of DTPA-Gd ${ }^{3+}$, for example, presents a water molecule bound directly to the metal coordination sphere (Lauffer, 1990). Thus, in order to be incorporated into micelles, such structures must acquire an amphiphilic nature (Torchilin, 1999).

Several chelating probes with an amphiphilic nature were previously developed for liposome membrane incorporation studies, such as DTPA-PE (Grant, Karlik, Florio, 1989), DTPA-stearylamine (DTPA-SA) (Kabalka et al., 1989), and amphiphilic acylated paramagnetic complexes of Mn and Gd (Unger et al., 1994). In these agents, a hydrophilic chelating residue is covalently linked to a hydrophobic (lipid) chain. The lipid part of the molecule can be anchored either in the liposome bilayer or the micelle's hydrophobic core while a more hydrophilic chelate is placed on the liposome surface or hydrophilic shell of the micelle. Incorporation of radioactive ion chelate allows the investigation of pharmacokinetic parameters in vivo, including blood half-life and biodistribution (Torchilin, 1999).

Amphiphilic chelating probes such as paramagnetic Gd-DTPA-PE and radioactive ${ }^{111}$ In-DTPA-SA were incorporated into $\mathrm{PEO}(5 \mathrm{kDa})-\mathrm{PE}$ micelles and used in vivo for MRI and scintigraphy techniques. The main feature of this kind of micelle useful in diagnostic imaging applications is their size (20 nm in diameter) (Rangel-Yagui, Pessoa Junior, Tavares, 2007).

Furthermore, it is not possible to prepare liposomes smaller than 70-100 nm owing to lipid bilayer curvature limitations (Enoch, Strittmatter, 1979). For some diagnostic applications, such as percutaneous lymphography, the administration of diagnostic particulates of a significantly smaller size is required (Torchilin, 1999). An experiment using polystyrene nanospheres showed that particulate uptake in the primary lymph node after subcutaneous injection is drastically increased when nanospheres having a diameter of less than $100 \mathrm{~nm}$ were used (Davis et al., 1993).

\section{POLYMERIC MICELLES FOR DIAGNOSIS OF SLN AND LYMPHATIC SYSTEM}

The optimum size of the colloidal particles remains an unresolved issue. However, the behavior of colloids injected interstitially depends on their particle size. Radiopharmaceutical colloidal preparations should have particulates with uniform size below $100 \mathrm{~nm}$, which are able to travel from the injection site and reach the lymphatic ducts and lymph nodes. Very large particles fail to migrate and tend to remain in the interstitium at the injection site whereas particles smaller than 4-5 nm travel so quickly that only a fraction is retained in the first (sentinel) lymph node (Nieweg et al., 1999; Henze et al., 1982; Ege, 1976). In addition, excessively small particles will likely cross the endothelium and promptly enter into blood circulation (Nieweg et al., 1999).

The most common radiopharmaceutical employed as an SLN localization agent is ${ }^{99 \mathrm{~m}} \mathrm{Tc}$-labeled sulfur colloid. Other radiopharmaceuticals used for this purpose have also been reported, including ${ }^{99 \mathrm{~m}} \mathrm{Tc}-$ labeled dextran, ${ }^{99 \mathrm{~m}}$ Tc hydroxyethyl starch (HES), ${ }^{99 \mathrm{~m}}$ Tc human serum albumin (HSA) and several labeled colloids, such as ${ }^{198} \mathrm{Au}-$ colloid, ${ }^{99 \mathrm{~m}} \mathrm{Tc}$ stannous phytate, ${ }^{99 \mathrm{~m}} \mathrm{Tc}$-antimony trisulfide colloid (ATC), ${ }^{99 \mathrm{~m}} \mathrm{Tc}$ rhenium colloid and ${ }^{99 \mathrm{~m}} \mathrm{Tc}$ colloidal albumin (Wilhelm, Mijnhout, Franssen, 1999).

However, none of these entirely fulfill the desired criteria of an ideal imaging agent, and the search for an optimal nanoparticulate radiopharmaceutical continues (Jain, Dandekar, Patravale, 2009). 
Trubetskoy and Torchilin (1995) synthesized a series of PEO-PE conjugates with molecular weights of $2 \mathrm{kDa}, 5$ $\mathrm{kDa}$ and $12 \mathrm{kDa}$. Micelles of different sizes were formed in an aqueous environment. Also, after serially diluting (up to $1 \mu \mathrm{mol} / \mathrm{mL}$ ) samples of $\mathrm{PEO}(5 \mathrm{kDa})$-PE no dissociation into individual polymeric chains was observed, confirming the stability of the micelles and indicating low values of CMC. They showed that PEO-PE micelles can efficiently incorporate some sparingly soluble and amphiphilic substances. However, as previously mentioned, the main feature that makes PEO-PE micelles attractive for diagnostic imaging applications is their size.

Trubetskoy and co-workers (1996) incorporated amphiphilic chelating probes $\mathrm{Gd}\left({ }^{111} \mathrm{In}\right)$-DTPA-PE and ${ }^{111}$ In-DTPA into PEO-PE micelles (20 nm in diameter) and tried to use these particulate agents in experimental percutaneous lymphography using gamma-scintigraphy and MRI in rabbits. Subcutaneous doses of $20 \mu \mathrm{Ci}$ administrated into the dorsum of a rabbit hind paw and into the popliteal lymph node (first lymph node draining the injection site) were visualized within seconds of injection. The findings were compared to the control ${ }^{111} \mathrm{In}-\mathrm{PEO}-$ liposomes (200 nm in diameter). Constituting small particles, micelles exhibit higher accumulation in the primary lymph node. Thus, the micellar particulates, due to their size and surface properties, can be moved easily from the injection site. Another experiment in the same study, using MRI of the axillary/subscapular lymph node area in rabbit, obtained after subcutaneous injection of small doses of Gd-DTPA-PE/PEO-PE micelles, showed that the collecting lymph vessel and axillary lymph node become visible only 4 min after administration of Gd-containing micelles.

Considering the ease and speed with which the primary lymph nodes may be visualized, the authors
(Trubetskoy et al., 1999) suggested that polymeric micelles are lymphangiographic in nature, unlike the other lymphotropic contrast media. The action of polymeric micelles is based upon the visualization of lymph flowing through different elements of the lymphatics whereas the other lymphotropic contrast media act based primarily on their active uptake by the nodal macrophages. In this case, lymph nodes become visible only after the concentration of the medium in the lymph node has reached a certain threshold value which usually requires prolonged periods of time (Torchilin, 2002).

DTPA is the most popular chelating agent for diagnostic heavy metals. Chelated paramagnetic metal moieties are of a hydrophilic nature and should acquire an amphiphilic nature in order to be incorporated into micelles (Torchilin, 2002). Several chelating probes of amphiphilic character were developed for liposome membrane incorporation studies (Unger et al., 1994; Grant, Karlik, Florio, 1989) and probably can also be used for micelle incorporation, such as the conjugate agent PEDTPA. In these agents, the hydrophilic chelating residue is covalently linked to a hydrophobic lipid chain. The lipid part of the molecule is anchored in the polymeric micelle's hydrophobic core (for example, PEO-PE), while the hydrophilic part containing the chelating moiety is located on the micelle hydrophilic polymer shell (surface), as illustrated in Figure 2 (Torchilin, 2002).

\section{POLYMERIC MICELLES FOR DIAGNOSIS AND CANCER THERAPY}

Cancer has been one of the major social and health concerns of the last ten decades. The use of nuclear medicine applications in oncology is of particular importance as

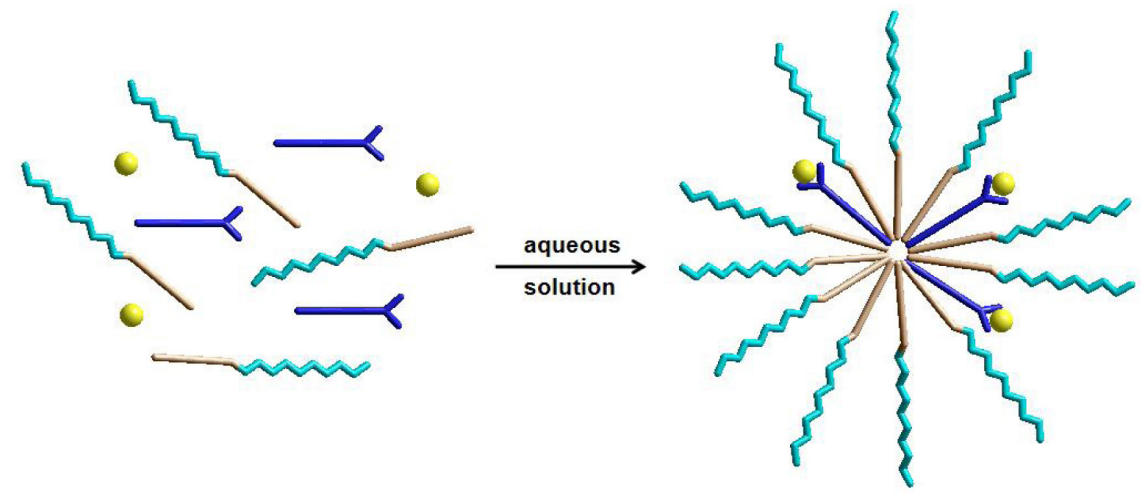

FIGURE 2 - Schematic representation of PEO-PE polymeric micelle formation labeled with ${ }^{99 \mathrm{~m}}$ Tc. Micelle is formed spontaneously in aqueous media by self-assembled amphiphilic polymers, such as PEO-PE units (the soluble and insoluble blocks are light blue and brown, respectively). The radioactive compound (yellow spheres) is incorporated into the micelle through the amphiphilic polychelating agent, PE-DTPA (dark blue). 
a rapidly developing therapeutic and diagnostic multimodality. The investigation of novel specific tumor-targeting radiopharmaceuticals is currently a potential field of interest for both cancer imaging (tumor scintigraphy, for example) and/or therapy (Hamoudeh et al., 2008).

Radiopharmaceuticals are dosage forms consisting of a carrier and a trace amount of a radionuclide, which has a defined radiation type(s). Hence, the efficacy of a radiopharmaceutical is determined by these two components (Hamoudeh et al., 2008; Grallert, Araujo, Tavares, 2003; Yokoyama et al., 1996). In tumor therapy, the therapeutic effect is due to the tumoral absorption of alpha $(\alpha)$ or beta $(\beta)$ radiation energy emitted by the radionuclide. As mentioned earlier, the ideal radiopharmaceutical should carry the radionuclide quantitatively to the tumor tissue with no radiation reaching normal tissues. Addressing this need, current progress in the pharmaceutical nanotechnology field has been exploiting the development of promising approaches for designing novel nano- and micro-carriers able to deliver radionuclides in a selective manner to improve the outcome of treatment and quality of diagnosis (Panchapakesan, Wickstrom, 2007).

The incorporation of anticancer agents into nanoparticulate or microparticulate carriers can be considered a useful means for controlling the tissular and cellular distribution profiles of these agents. This rational approach combines a controlled-release drug with targeted delivery in order to provide more efficient and less harmful solutions that overcome conventional chemotherapy limitations (Gu et al., 2007; Brigger, Dubernet, Couvreur, 2002).

Moreover, combining the more recent nuclear imaging multimodalities, which provide high sensitivity and anatomical resolution such as PET/CT and SPECT/CT, with the use of specific tumor-targeting radiopharmaceuticals, constitutes a promising strategy that will allow for earlier tumor detection, better treatment planning and more effective therapy, in the near future (Jain, Patravale, 2009; Pan et al., 2009; Hamoudeh et al., 2008).

Many polymeric micelle types have been proposed as carriers for anticancer therapeutic and diagnostic agents including paclitaxel (Zhang, Jackson, Burt, 1996), doxorubicine (Yokoyama et al., 1990), cisplatin (Yokoyama et al., 1996) and Gd-DTPA (Trubetskoy et al., 1996). The use of micelles as possible carriers for tumor imaging agents involves the following factors: (i) the incorporation of gamma emitters such as ${ }^{111} \mathrm{In}$ or ${ }^{99 \mathrm{~m}} \mathrm{Tc}$ for gamma scintigraphy (Reddy, Sharma, Murthy, 2006; Trubetskoy, Torchilin, 1996); (ii) the incorporation of paramagnetic gadolinium complexes for MRI application (Kabalka, 1989; Torchilin, 1994); and, (iii) X-ray computed to- mography using iodine-containing polymeric micelles (Torchilin, Frank-Kamenetsky, Wolf, 1999; Trubetskoy et al., 1997).

An application of polymeric micelles as tumor imaging agents was reported by Torchilin (2002). PEO-PE-DTPA immunomicelles labeled with ${ }^{111}$ In and attached to a 2C5-antibody against Murine Lewis lung carcinoma (LLC) have been used to image the LCC. A micelle intra-tumoral accumulation enhancement of $30 \%$ was observed for immunomicelles in comparison to unmodified micelles. It is noteworthy that to date, no studies on tumor targeted radiotherapy by micelles have been reported in the literature.

\section{MOLECULAR MODELLING AND CADD APPLIED TO DEVELOPMENT OF RADIOPHARMACEUTICALS}

The role of CADD in the pipeline of drug discovery, including radiopharmaceuticals, is accelerating the discovery of new lead compounds and their structure optimization for the pharmacological tests that follow (Salvadori, 2008; Veselovsky, Ivanov, 2003). The main directions in CADD are based upon the availability of the experimentally determined three-dimensional (3D) structure of the target macromolecule. If the target 3D structure is known, the methods of structure-based drug design (SBDD) are used. SBDD is perhaps the most elegant approach for discovering compounds exhibiting specificity and efficacy. Otherwise, when the target 3D structure is not available, the indirect methods of CADD based upon the 3D structures of known ligands (ligand-based drug design, LBDD) are performed (Leach, 2001; Veselovsky, Ivanov, 2003; Salvadori, 2008; Wermuth, 2008).

CADD or CAMD (Computer-Aided Molecular Design) can provide the $3 \mathrm{D}$ structure of a molecule, its chemical and physical characteristics, comparisons of structures of different molecules, and visualization of complexes formed between them. Additionally, predictions may be made about how related new molecules may function. Thus, the combination of quantum and/or molecular mechanics and also formalisms of quantitative structure-activity relationships (QSAR) constitutes a formidable arsenal for rationally designing novel therapeutic and diagnostic agents. The molecular modeling approaches are tools of CADD and can provide electronic and thermodynamic data which are not available from X-ray crystallographic data, for example. Indeed, these formalisms are not confined to radiopharmaceuticals development and can equally aid the development of contrast agents for imaging tissues, organs and tumors (Boudreau, 
Efrange, 1992). Here, the applications of molecular modeling methods were investigated in radiopharmaceuticals containing peptide derivatives as a bioactive agent.

Classes of radiopharmaceuticals are being distinguished according to the applied design strategy. "Metal essential or first generation agents" are typically relatively small complexes in which the radioactive metal center is chelated with oxygen, sulfur, nitrogen or phosphorus atoms containing ligands which can be further functionalized with additional groups, such as the tissue-selective heart imaging agent Cardiolite ${ }^{\circledR}\left({ }^{99 \mathrm{~m}} \mathrm{TcMIBI}_{6}{ }^{+}\right.$; MIBI: 1-isocyano-2-methoxy-methylpropane). The molecular parameters including size, charge state and solvation properties (hydrophilicity/lipophilicity) seems to be among the key factors governing the tissue-specific accumulation of first generation agents. Heart specific agents might be characterized by lipophilicity and unipositive charge whereas brain specific agents are mostly neutral and moderately lipophilic. "Conjugate or second generation agents" are increasing in specificity and the complex containing the radioactive nucleus is covalently linked to a monoclonal antibody or a biologically active molecule which binds to specific receptor sites. A similar approach led to the development of "integrated or third generation agents" in which the outer sphere of the chelating ligand contains the sites for receptor binding, meaning the ligand itself mimics a biologically active molecule, for example, a steroid hormone such as estradiol or testosterone (Dilworth, Parrott, 1998; Guidoni et al., 2002).

Reichert and Welch (2001) reported applications of molecular mechanics methodologies to metal-based imaging agents. They developed parameters for a commercially available modeling package capable of reproducing experimentally determined structures, such as octahedral $\mathrm{Ga}(\mathrm{III})$ and In(III), Tc(V) mono-oxo complexes, and Gd(III). Also, they discussed the use of a technique known as the coordination scan which allows the determination of the sterically preferred coordination state of a metal in a given metal-ligand complex.

This seems to be useful for the prediction of in vivo stability. If the metal coordinated by a particular ligand possesses vacant coordination sites, it frequently displays low in vivo stability. This application can be particularly valuable in understanding the behavior of Gd-based MRI agents.

A common technique in the design of targeted radiopharmaceuticals is the use of bifunctional chelates which are conjugated to a previously developed substrate for the receptor of interest. Molecular modeling is of great utility in addressing the question of whether this modification to the substrate will have a negative impact on receptor binding. Considering this, Reichert and Welch (2001) also carried out molecular modeling studies of bifunctional chelate peptide conjugates. These authors developed parameters for $\mathrm{In}(\mathrm{III})$ and $\mathrm{Cu}$ (II) for the AMBER force field using automated procedures from a combination of crystallographic structures and ab initio calculations. The new parameters produced resulted in good agreement with the experimental data. Subsequently, these were used to examine the conformational effects caused by the conjugation of ${ }^{111}$ In-DTPA to the cyclic octapeptide octreotide, the widely used imaging agent OctreoScan (72), and the conjugation of ${ }^{64} \mathrm{Cu}$-DOTA (DOTA $=1,4,7,10$-tetraazacyclododecane-1,4,7,10-tetraacetic acid) to the parent peptide (the somatostatin (SST) analogue octreotide, sandostatin) (Figure 3). The ${ }^{111}$ In-OctreScan was the first diagnostic radiopeptide approved by the FDA for scintigraphy of patients with neuroendocrine tumors (Okarvi, 2008). The recent introduction of the metal chelator DOTA(Figure 4) considerably improved the stability of the radioconjugates, allowing incorporation of a variety of radionuclides for applications from receptor-mediated radionuclide therapy to PET (Froidevaux, Eberle, 2002).

The higher expression of peptide receptors in many tumor cells compared with normal tissues accelerated the development of radiolabeled small peptides for diagnostic imaging and radionuclide therapy in nuclear oncology where these receptors are considered potential molecular targets (see Figure 5) (Okarvi, 2008). Many naturally occurring peptides exhibit extremely high affinities (nano- or subnano-molar range) for cell-surface receptors. The successful development of new radiolabeled receptor-binding peptide analogues is dependent upon the molecular modifications of a given natural peptide, preserving the original binding affinity for the target receptors. A few of these peptides, such as SST, bombesin, cholecystokinin/gastrin, neurotensin and vasoactive intestinal peptide are currently under investigation for their possible clinical applications in nuclear oncology (Okarvi, 2008).

Nikiforovich and co-workers (2007) applied molecular modeling methodologies to a set of SST analogues for suggesting conformational scaffolds specifically targeting five subtypes of SST receptors (SSTRs, SSTR1 to SSTR5), which are overexpressed in gastroenteropancreatic, pituitary and carcinoid tumors, for example.

Most tumors exhibit overexpression of SSTR2 (breast cancer, carcinoid, neuroblastoma, etc.). SSTR5 overexpression is also present in growth hormone (GH)-expressing pituitary adenoma and kidney cancer. SSTR4 is overexpressed in ovary cancer whereas SSTR1, SSTR2, SSTR3 and SSTR5, simultaneously, are all overexpressed in thyroid cancer (Reubi, 2003; Froidevaux, Eberle, 2002). 


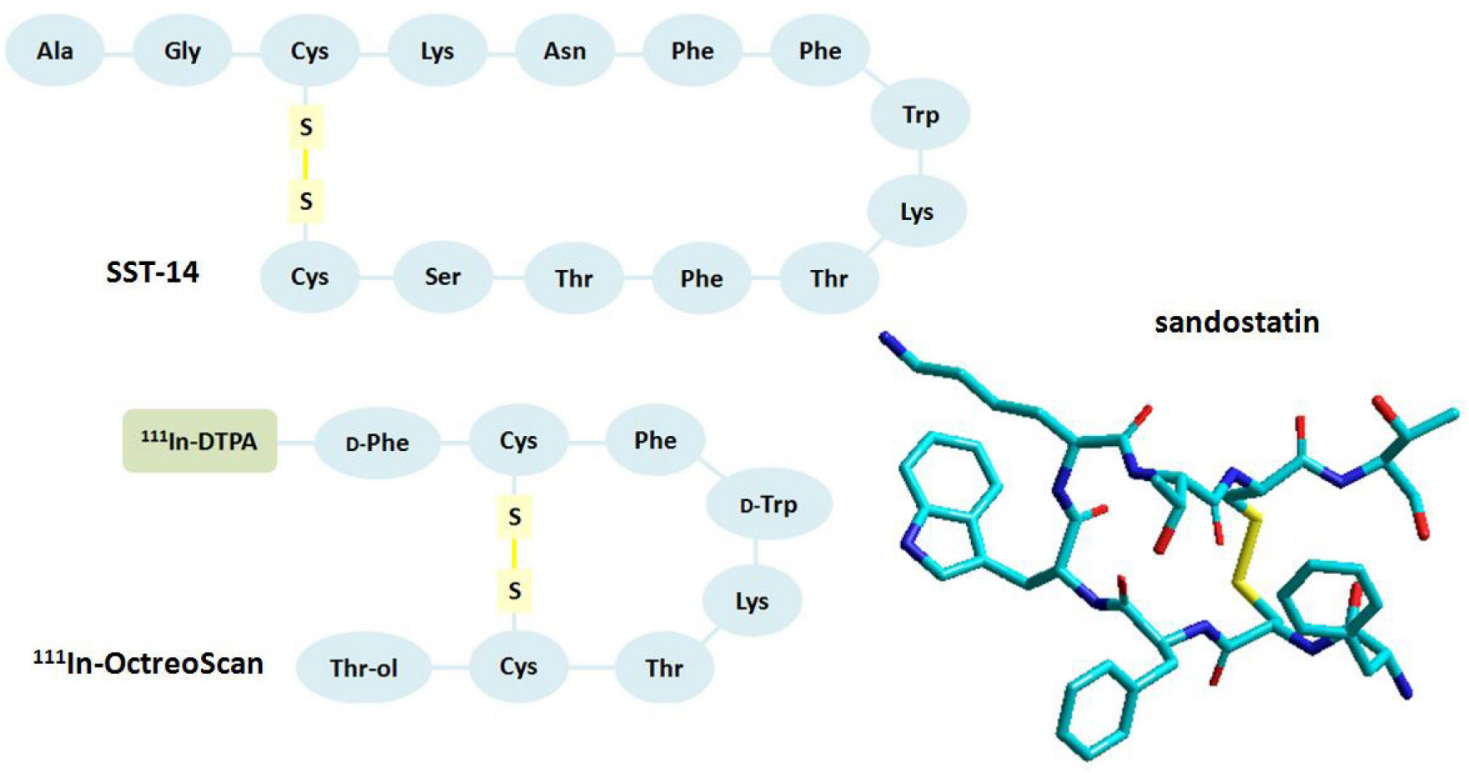

FIGURE 3 - Amino acid residue sequences for SST-14 and ${ }^{111}$ In-OctreoScan (adapted from Okarvi, 2008), and the 3D structure of sandostatin retrieved from PDB entry code 1SOC (Melacini, 1997). The hydrogen atoms not shown in the 3D-model. Carbon atoms are shown in light blue, nitrogen in dark blue, oxygen in red, and sulfur in yellow.
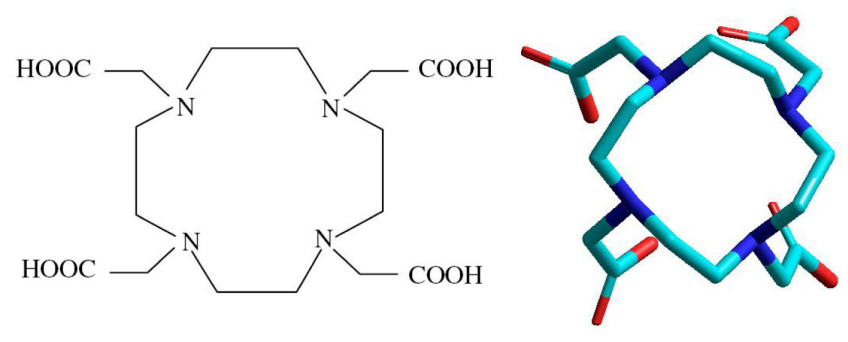

FIGURE 4 - Chemical structure of DOTA and its respective 3D-model extracted from PDB entry code 1NC4 (Corneillie, Fischer, Meares, 2003). The hydrogen atoms are not displayed in the 3D-model. Carbon atoms are shown in light blue, nitrogen in dark blue and oxygen in red.

The authors (Nikiforovich, Marshal, Archilefu, 2007) compared the low-energy backbone structures of the investigated peptides and suggested unique conformations of the central fragment (Phe/Ala-DTrp-Lys-Thr) characteristic of specific interactions of SST with each of the five distinct subtypes of SSTRs.

The resulting conformations were in good agreement with experimental data obtained earlier by NMR measurements and/or X-ray crystallography, and may serve as conformational templates for rational design of non-peptide scaffolds which effectively and selectively interact with different SSTRs subtypes.

Bombesin $(\mathrm{BN})$ is a 14-amino acid neuropeptide (Figure 6) which shows high affinity for the human gastrin-releasing peptide (GRP) receptor overexpressed by

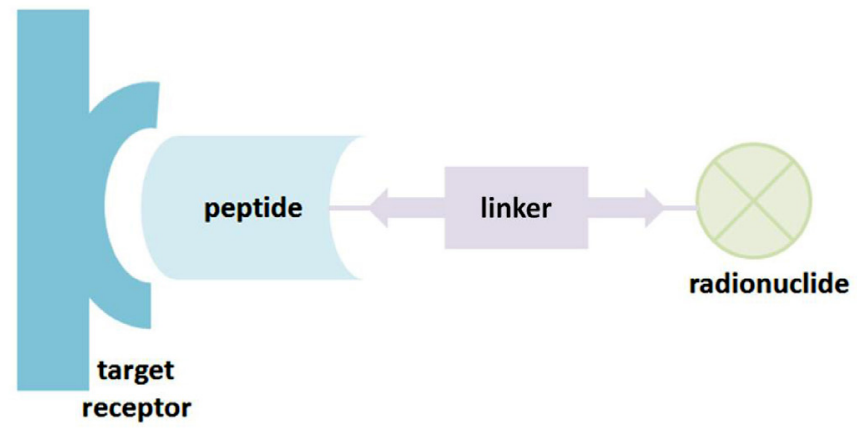

FIGURE 5 - Schematic representation of strategy to target receptor with peptide radiopharmaceutical (Adapted from Okarvi, 2008).

a variety of cancers, including prostate, breast, pancreas, gastrointestinal, and small cell lung cancer (Okarvi, 2004; Reubi, 2003). High expression of BN/GRP receptors in various tumors provides an attractive target for BN/GRP receptor scintigraphy and radionuclide therapy (Fleishmann et al., 2005; Okarvi, 2004).

The C-terminal 7-14 amino acid sequence (GlnTrp-Ala-Val-Gly-His-Leu-Met- $\mathrm{NH}_{2}$ ) of BN-like peptides is known to be critical for receptor binding affinity and biological activity (Smith, Volkert, Hoffman, 2005). Most radiolabeled BN-like peptides are based on the 7-14 amino acid sequence, coupled with a chelator through a spacer group at the N-terminus of the peptide (Smith, Volkert, Hoffman, 2005; Okarvi, 2004). Also, much attention has been focused on developing ${ }^{99 \mathrm{~m} T c-l a b e l e d ~ B N-l i k e ~ p e p-~}$ 


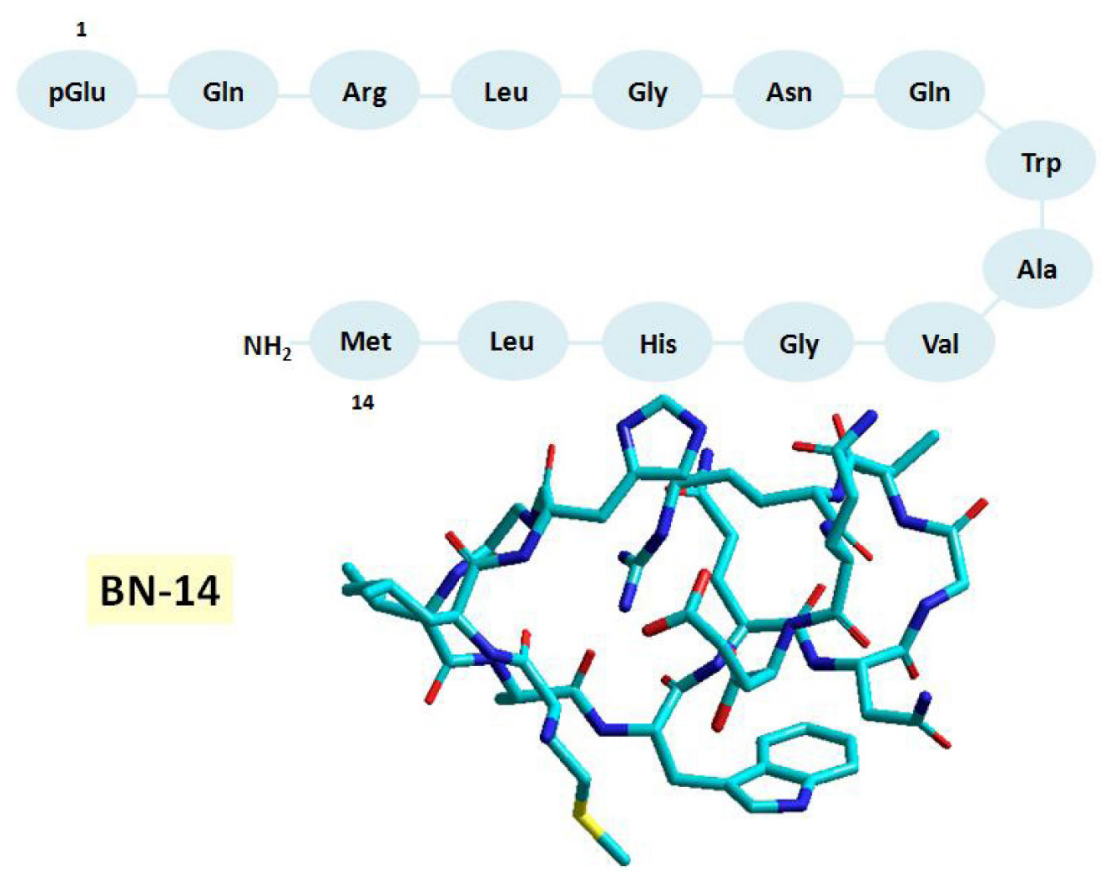

FIGURE 6 - Amino acid residue sequence for BN-14 (Okarvi, 2008) and BN 3D-model selected from molecular dynamics simulation of $100 \mathrm{ps}$ at $310 \mathrm{~K}$. The hydrogen atoms not shown. Carbon atoms shown in light blue, nitrogen in dark blue, oxygen in red, and sulfur in yellow.

tides with different types of chelators, peptide sequences and spacer groups (Okarvi, 2004). Araújo and co-workers (2009) submitted an innovative project on molecular labeled radionuclide $\mathrm{BN}$ derivatives for diagnosis and therapy of tumors which overexpress GRP receptors to the National Institute of Industrial Property (Instituto $\mathrm{Na}$ cional da Propriedade Industrial, INPI) requesting patent reservation (Araujo, Pujatti, Grallert, 2009). Currently, experimental and molecular modeling studies of a set of promising $\mathrm{BN}$-like peptides as novel radiopharmaceuticals have been performed by researchers from the Center for Radiopharmacy at the Institute of Nuclear and Energy Research (Instituto de Pesquisas Energéticas e Nucleares, IPEN-CNEN/SP) in partnership with researchers from the Research Laboratory of Design and Development of Drugs (Laboratório de Planejamento e Desenvolvimento de Fármacos, LPDF - Faculty of Pharmaceutical Sciences, University of Sao Paulo).

\section{RECENT STUDIES IN BRAZILIAN INSTITUTIONS}

The Institute of Nuclear and Energy Research (IPEN/SP), which is linked to the State of Sao Paulo Secretary of Science, Technology and Economic Development and managed technically, administratively and financially by the National Commission of Nuclear Energy (Comissão
Nacional de Energia Nuclear, CNEN), holds the production monopoly of radiopharmaceuticals labeled with radioisotopes of long half-life and also supplies several products nationwide, such as primary radioisotopes, labeled compounds, and lyophilized reagents ready to be labeled with ${ }^{99 m} \mathrm{Tc}$. The IPEN's main facilities include a nuclear research reactor and a $30 \mathrm{MeV}$ cyclotron for producing radioisotopes for use in medicine, industry and research.

The development of radiopharmaceuticals for detection of SLN demands prior investment in multiple centers bearing automated technology and quality control for producing positron-emitting radionuclides of short or ultrashort half-life, such as ${ }^{11} \mathrm{C},{ }^{13} \mathrm{~N}$ or ${ }^{18} \mathrm{~F}$. Therefore, the use of PET modality for SLN imaging is not yet a reality in Brazil.

However, PET imaging technology is already implemented in several hospitals and clinics in Sao Paulo city and, to a lesser extent, in nuclear medicine facilities in other regions of the country for the diagnosis of specific tumors, employing $\left({ }^{18} \mathrm{~F}\right)$-2-fluoro-2-deoxyglucose $\left({ }^{18} \mathrm{~F}\right.$ FDG) as the radiopharmaceutical.

The ${ }^{18} \mathrm{~F}$ has a relatively long half-life (110 minutes) in comparison to the other PET radionuclides outlined above. Thus, it can be produced at a regional centre, for example, and be distributed to local hospitals whereas other radionuclides need to be produced on site (84).

Alternatively, SPECT is a technique widely used and gamma-emitting radioisotopes, such as ${ }^{99 \mathrm{~m}} \mathrm{Tc}$ and ${ }^{123} \mathrm{I}$, 
labeling molecules with potential characteristics as radiotracers for mapping the lymphatic system are routinely produced by IPEN.

From this perspective, the development of a methodology for preparation of polymeric micelles labeled with ${ }^{99 \mathrm{~m}} \mathrm{Tc}$ would render radiochemical and biological investigations feasible, which are necessary for the design of a novel radiopharmaceutical with potential clinical application in diagnostic nuclear medicine. The research group of the Laboratory of Design and Development of Drugs (Laboratório de Planejamento e Desenvolvimento de Fármacos, LPDF - Faculty of Pharmaceutical Sciences, University of Sao Paulo) in partnership with the Center for Radiopharmacy (IPEN-CNEN) has developed a new radiopharmaceutical containing mixed polymeric micelles of PEO-PE-99m Tc while important results using the scintigraphy imaging modality in New Zealand rabbits were obtained regarding the visualization of lymphatic paths and SLN. Based upon these results and considering that this research area is still a restricted field in Brazil, the authors submitted the new compound to the INPI requesting patent reservation.

\section{CONCLUSION}

Polymeric micelles composed of copolymers represent a promising class for diagnostic nuclear medicine. Radioisotopes as well as paramagnetic metals can be easily attached to the hydrophilic portions or non-covalently incorporated into the hydrophobic core. These copolymers spontaneously form colloidal particulates in aqueous solution, which measure from 10 to $100 \mathrm{~nm}$ in diameter depending on the molecular weight of the polymer block.

Polymeric micelles in particular have an excellent ability to solubilize poorly water-soluble drugs in vivo and increase their bioavailability. Moreover, the reduced particle size confers them efficient accumulation in areas of the body with low permeability and also areas of compromised vasculature.

Although this research field is relatively new, some approaches involving the application of polymeric micelles as carriers of radiopharmaceuticals, radioisotopes, and contrast agents, for diagnostic/imaging use in nuclear medicine employing PEO and PE polymers labeled with ${ }^{111} \mathrm{In}$ or ${ }^{99} \mathrm{mTc}$, preferably, have shown promising results especially for SLN imaging, visualization of lymphatic pathways and diagnosis of some types of tumors, such as breast and prostate cancers.

Small peptides continue to play an important role in the diagnosis and treatment of cancers. The increasing evidence of peptide receptor overexpression in several human cancers serves as a trigger for the development of peptides for selective in vivo targeting of these tumors. In this sense, the application of molecular modeling methodologies and some CADD strategies can be extremely useful for providing information that aids the rational design and development of novel radiopharmaceuticals.

\section{ACKNOWLEDGEMENTS}

This work was supported by FAPESP, CAPES, and CNPq. Grallert S.R.M would like to thank CNPq for the post-doctoral fellowship.

\section{REFERENCES}

ALEXIS, F.; RHEE, J.W.; RICHIE, J.P; RADOVIC-MORENO, A.F.; LANGER, R.; FAROKHZAD, O.C. New frontiers in nanotechnology for cancer treatment. Urol. Onc.: Sem. and Orig. Invest., v.26, p.74-85, 2008.

ARAÚJO, E.B.; PUJATTI, P.B.; GRALLERT, S.R.M. Micelas poliméricas de polióxido de etileno e fosfatidiletanolamina, PEO-PE, como radiofármaco para diagnóstico de vias linfáticas e pesquisa de linfonodo sentinela. Br Pat. $020090062895,26^{\text {th }}$ jun 2009.

BAKKER, W.H.; ALBERT, R.; BRUNS, C.; BREEMAN, W.A.P.; HOFLAND, L.J.; MARBACH, P.; PLESS, J.; PRALET, D.; STOLZ, B.; KOPER, J.W.; LAMBERTS, S.W.J.; VISSER, T.J.; KRENNING, E.P. (111In-DTPAD-Phe1)-octreotide, a potential radiopharmaceutical for imaging of somatostatin receptor-positive tumors: synthesis, radiolabeling and in vitro validation. Life Sci., v.49, p.1583-1591, 1991.

BANGHAM, A.D.; STANDISH, M.M.; WATKINS, J.C. Diffusion of univalent ions across the lamellae of swollen phospholipids. J. Mol. Biol., v.13, p.238-252, 1965.

BOUDREAU, R.J., EFANGE, S.M. Computer-aided radiopharmaceutical design. Invest. Radiol., v.27, p.653$658,1992$.

BRIGGER, I.; DUBERNET, C.; COUVREUR, P. Nanoparticles in cancer therapy and diagnosis. Adv. Drug Deliv. Rev., v.54, p.631-651, 2002.

CHEVALIER, Y.; ZEMB, T. The structure of micelles and microemulsions. Rep. Prog. Phys., v.53, p.279-371, 1990. 
CORNEILLIE, T.M.; FISHER, A.J.; MEARES, C.F. Crystal structures of two complexes of the rare-earth-DOTAbinding antibody 2D12.5: Ligand generality from a chiral system. J. Am. Chem. Soc., v.125, p.15039-15048, 2003.

DAVIS, S.S.; ILLUM, L.; MOGHIMI, S.M.; DAVIES, M.C.; PORTER, C.J.H.; MIUR, I.S.; BRINDLEY, A.; CHRISTY, N.M; NORMAN, M.E.; WILLIAMS, P.; DUNN, S.E. Microspheres for targeting drugs to specific body sites. $J$. Control. Release, v.24, p.157-163, 1993.

EGE, G.N. Internal mammary lymphoscintigraphy. Radiology, v.118, p.101-107, 1976.

ELLERHORST, J.A.; BEDIKIAN, A.; RING, S.; BUZAID, A.C.; ETON, O.; LEGHA, S.S. Phase II trial of doxil for patients with metastatic melanoma refractory to frontline therapy. Oncol. Rep., v.6, p.1097-1099, 1999.

ENOCH, H.G.; STRITTMATTER, P. Formation and properties of 1000-A-diameter, single-bilayer phospholipid vesicles. Proc. Natl. Acad. Sci. USA, v.76, p.145-149, 1979.

FERRARI, M. Cancer nanotechnology: opportunities and challenges. Nat. Rev. Cancer, v.5, p.161-171, 2005.

FLEISCHMANN, A.; WASER, B.; GEBBERS J.O.; REUBI, J.C. Gastrin releasing peptide receptors in normal and neoplastic human uterus: involvement of multiple tissue compartments. J. Clin. Endocrinol. Metab., v.90, p.47224729, 2005.

FROIDEVAUX, S., EBERLE A. Somatostatin analogs and radiopeptides in cancer therapy. Biopolymers, v.66, p.161$183,2002$.

GOINS, B.A.; PHILLIPS, W.T. The use of scintigraphic imaging as a tool in the development of liposome formulations. Prog. Lipid Res., v.40, p.95-123, 2001.

GRALLERT, S.R.M. Flavone and analogues as radioligands for brain imaging. Synthesis, labeling with radioiodine and in vivo studies using benzodiazepine receptors. São Paulo, 2006. 174p. [Thesis of PhD degree. Faculty of Pharmaceutical Sciences, University of São Paulo].

GRALlERT, S.R.M.; ARAÚJO, E.B; TAVARES, L.C. Radioligands for benzodiazepine receptors. Braz. J. Pharm. Sci., v.39, p.243-257, 2003.
GRANT. C.W.M.; KARLIK, S.; FLORIO, E. A liposomal MRI contrast agent: Phosphatidylethanolamine-DTPA. Magn. Resson. Med., v.11, p.236-243, 1989.

GREEN, M.R.; MANIKHAS, G.M.; ORLOV, S.;AFANASYEV, B.; MAKHSON, A.M.; BHAR, P.; HAWKINS, M.J. Abraxane ${ }^{\circledR}$, a novel Cremophor $\AA$-free, albumin-bound particle form of paclitaxel for the treatment of advanced non-small-cell lung cancer. An. Oncol., v.17, p.1263-1268, 2006.

GU, F.X.; KARNIK, R.; WANG, A.Z.; ALEXIS, F.; LEVYNISSENBAUM, E.; HONG, S.; LANGER, R.S.; FAROKHZAD, O.C. Targeted nanoparticles for cancer therapy. NanoT., v.2, p.14-21, 2007.

GUIDONI, L.; MAURER, P.; PIANA, S.; ROTHLISBERGER, U. Hybrid Car-Parrinello/molecular mechanics modelling of transition metal complexes: Structure, dynamics and reactivity. Quant. Struct.-Act. Relat., v.21, p.119-127, 2002.

HAMOUDEH, M.; KAMLEH, M.A.; DIAB, R.; FESSI, H. Radionuclides Delivery systems for nuclear imaging and radiotherapy of cancer. Adv. Drug Del. Sys., v.60, p.13291346, 2008.

HENZE, E.; SCHELBERT, H.R.; COLLINS, J.D.; NAJAFI, A.; BARRIO, J.R.; BENNET, L.R. Lymphoscintigraphy with 99mTc-labeled dextran. J. Nucl. Med., v.23, p.923929, 1982.

JAIN, R.; DANDEKAR, P.; PATRAVALE, V. Diagnostic nanocarriers for sentinel lymph node imaging. J. Control. Release, v.138, p.90-102, 2009.

KABALKA, G.; BUONOCORE, E.; HUBNER, K.; DAVIS, M.; HUANG, L. Gadolinium-labeled liposomes containing paramagnetic amphipathic agents targeted MRI contrast agent for the liver. Magn. Res. Med., v.8, p.89-95, 1989.

KABANOV, A.V.; BATRAKOVA, E.V.; MELIK-NUBAROV, N.S.; FEDOSEEV, N.A.; DORODNICH, T.Y.U.; ALAKHOV, V.Y.U.; CHEKHONIN, V.P.; NAZAROVA, I.R.; KABANOV, V.A. A new class of drug carriers; micelle poly(oxyethylene)-poly(oxypropylene) block copolymers as microcontainers for drug targeting from blood to brain. J. Control. Release, v.22, p.141-158, 1992.

KOWALSKY, J.R.; FALEN, S.W. Radiopharmaceuticals in nuclear pharmacy and nuclear medicine. 2.ed. Washington: Nancy tarleton landis, 2004. 825 p. 
KWON, G.S. Diblock copolymer nanoparticles for drug delivery. Crit. Rev. Ther. Drug Carrier Syst., v.15, p.481512,1998 .

KWON, G.S.; KATAOKA, K. Block copolymer micelles as long circulating drug vehicles. Adv. Drug Deliv. Rev., v.16, p.295-309, 1995.

LARINA, I.V.; EVERS, B.M.; ASHITKOV, T.V.; BARTELS, C.; LARIN, K.V.; ESENALIEV, R.O. Enhancement of drug delivery in tumors by using interaction of nanoparticles with ultrasound radiation. Technol. Cancer Res. Treat., v.4, p.217-226, 2005.

LASIK, D.D. Mixed micelles in drug delivery. Nature, v.355, p.279-280, 1992.

LAUFFER, R.B. Magnetic resonance contrast media: principles and progress. Magn. Reson. Quart., v.6, p.65-84, 1990.

MAGNUSSON, G.; OLSSON, T.; NYBERG, J.A. Toxicity of pluronic f-68. Toxicol. Lett., v.30, p.203-210, 1986.

MELACINI, G.;ZHU, Q.; GOODMAN, M. Multiconformational NMR analysis of sandostatin (octreotide): Equilibrium between b-sheet and partially helical structures. Biochemistry, v.36, p.1233-1241, 1997.

NAKAMURA, E.; MAKINO, K.; OKANO, T.; YAMAMOTO, T.; YOKOYAMA, M. A polymeric micelle MRI contrast agent with changeable relaxivity. J. Control. Release, v.114, p.325-333, 2006.

NASONGKLA, N.; BEY, E.; REN, J.; AI, H.; KHEMTONG, C.; GUTHI, J.S.; CHIN, S.F.; SHERRY, A.D.; BOOTHMAN, D.A.; JINMING GAO, J. Multifunctional polymeric micelles as cancer-targeted, MRI-ultrasensitive drug delivery systems. Nano Lett., v.6, p.2427-2430, 2006.

NIEWEG, O.E.; JANSEN, L.; OLMOS, R.A.V.; RUTGERS, E.J.T.H.; PETERSE, J.L.; HOEFNAGEL, K.A.; KROON, B.B.R. Lymphatic mapping and sentinel lymph node biopsy in breast cancer. Eur. J. Nucl. Med., v.26, p.S11-S16, 1999.

NIKIFOROVICH, G.V.; MARSHALL, G.R.; ACHILEFU, S. Molecular modeling suggests conformational scaffolds specifically targeting five subtypes of somatostatin receptors. Chem. Biol. Drug Des., v.69, p.163-169, 2007.
NIKURA, H.; OKAMURA, C.; UTSUNOMIYA, H.; YOSHINAGA, K.; AKAHIRA, J.; ITO, K.; YAEGASHI, N. Sentinel lymph node detection in patients with endometrial cancer. Gynecol. Oncol., v.92, p.669-674, 2004.

OKARVI, S.M. Peptide-based radiopharmaceuticals: future tools for diagnostic imaging of cancers and other diseases. Med. Res. Rev., v.24, p.357-397, 2004.

PADUANO, L.; VACCARO, M.; ACCARDO, A.; MORELLI, G.; TESAURO, D.; SCHILLEN, K.; RADULESCU, A.; D'ERRICO, G. Peptides and Gd complexes containing colloidal assemblies as tumor specific contrast agents in MRI: physicochemical characterization. Biophys. J., v.93, p.1736-1746, 2007.

PAN, D.; LANZA, G.M.; WICKLINE, S.A.; CARUTHERS, S.D. Nanomedicine: Perspective and promises with liganddirected molecular imaging. Eur. J. Radiol., v.70, p.274285, 2009.

RANGEL-YAGUI, C.O.; HSU, H.W. L.; PESSOA JUNIOR, A.; TAVARES, L.C. Micellar solubilization of ibuprofen: the influence of surfactant head on the extent of solubilization. Braz. J. Pharm. Sci., v.41, p.237-245, 2007.

RANGEL-YAGUI, C.O.; PESSOA JUNIOR, A.; TAVARES, L.C. Micellar solubilization of drugs. Can. J. Pharm. Sci., v.8, p.147-163, 2005.

RAPOPORT, N.; Physical stimuli-responsive polymeric micelles for anti-cancer drug delivery. Prog. Polym. Sci., v.32, p.962-990, 2007.

REDDY, L.H.; SHARMA, R.K.; MURTHY, R.R. Enhanced delivery of etoposide to dalton's lymphoma in mice through polysorbate 20 micelles. Acta Pharm., v.56, p.143-155, 2006.

REICHERT, D.E.; WELCH, M.J. Applications of molecular mechanics to metal-based imaging agents. Coord. Chem. Rev., v.212, p.111-131, 2001.

REICHERT, D.E.; WELCH, M.J. Molecular modeling of bifunctional chelate peptide conjugates. 1. Copper and Indium parameters for the AMBER force field. Inorg. Chem., v.40, p.5223-5230, 2001.

REUBI, J.C. Peptide receptors as molecular targets for câncer diagnosis and therapy. Endocr. Rev., v.24, p.389-427, 2003. 
SALVATORI, P.A. Radiopharmaceuticals, drug development and pharmaceutical regulations in Europe. Curr. Radiopharm., v.1, p.7-11, 2008.

SHAH, P.; WESTWELL, A.D. The role of fluorine in medicinal chemistry. J. Enz. Inhib. Med. Chem., v.22, p.527-540, 2007.

SENER, S.F.; WINCHESTER, D.J.; BRINKMANN, E.; WINCHESTER, D.P.; ALWAWI, E.; NICKOLOV, A.; PERLMAN, R.; BILIMORIA, M.; BARRERA, E.; BENTREM, D. Failure of sentinel lymph node mapping in patients with breast cancer. J. Am. Coll. Surg., v.198, páginas?, 2004.

SCHMEIDL, U.P.; NELSON, J.A.; TENG, L.; STARR, F.; MALEK, R.; HO, R.J. Magnetic resonance imaging of the hepatobiliary system: intestinal absorption studies of manganese mesoporphyrin. Acad. Radiol., v.2, p.994-999, 1995.

SLINKIN, M.A.; KLIBANOV, A.L.; TORCHILIN, V.P. Terminal-modified polylysine-based chelating polymers: highly efficient coupling to antibody with minimal loss in immunoreactivity. Bioconjugate Chem., v.2, p.342-348, 1991.

SMITH, C.J., VOLKERT, W.A.; HOFFMAN, T.J. Radiolabeled peptide conjugates for targeting of the bombesin receptor superfamily subtypes Nucl. Med. Biol., v.32, p.733-740, 2005.

SOO, P.L.; LUO, L.; MAYSINGER, D.; EISENBERG, A. Incorporation and release of hydrophobic probes in biocompatible polycaprolactone-block-poly(ethylene oxide) micelles: implications for drug delivery. Langmuir, v.18, p.9996-10004, 2002.

TORCHILIN, V.P. Polymer micelles in diagnostic imaging. Colloid. Surf. B., v.16, p.305-319, 1999.

TORCHILIN, V.P.; PEG-based micelles as carriers of contrast agents for different imaging modalities. Adv. Drug Deliv. Rev., v.54, p.235-252, 2002.

TORCHILIN, V.P Multifunctional carriers. Adv. Drug Deliv. Rev., v.58, p.1532-1555, 2006.

TORCHILIN, V.P. Structure and design of polymeric surfactantbased drug delivery systems. J. Control. Release, v.73, p.137-172, 2001.
TORCHILIN, V.P.; FRANK-KAMENETSKY, M.D.; WOLF, G.L.; CT visualization of blood pool in rats by using longcirculating, iodine-containing micelles. Acad. Radiol., v.6, p.61-65. 1999.

TORCHILIN, V.P.; TRUBETSKOY, V.S. New approaches in the chemical design of gd-containing liposomes for use in magnetic resonance imaging of lymph nodes. J. Liposome Res., v.4, p.961-980, 1994.

TORCHILIN, V.P. Micellar nanocarriers: pharmaceutical perspectives. Pharm. Res., v.24, p.1-16, 2007.

TORCHILIN, V.P. Recent advances with liposomes as pharmaceutical carriers. Nat. Rev. Drug Discov., v.4, p.145$160,2005$.

TRUBETSKOY, V.S.; FRANK-KAMENETSKY, M.D.; WHITEMAN, K.R.; WOLF, G.L.; TORCHILIN, V.P. Stable polymeric micelles: lymphangiographic contrast media for gamma scintigraphy and magnetic resonance imaging. Acad. Radiol., v.3, p.232-238, 1996.

TRUBETSKOY, V.S. Polymeric micelles as carriers of diagnostic agents. Adv. Drug. Deliv. Rev., v.37, p.81-88, 1999.

TRUBETSKOY, V.S.; GAZELLE, G.S.; WOLF, G.L.; TORCHILIN, V.P. Block copolymer of polyethylene glycol and polylysine as a carrier of organic iodine: design of a long circulating particulate contrast medium for X-ray computed tomography. J. Drug Target, v.4, p.381-388, 1997.

TRUBETSKOY, V.S.; TORCHILIN, V.P. Polyethylene glycol based micelles as carriers of therapeutic and diagnostic agents. STP Pharm. Sci., v.6, p.79-86, 1996.

TRUBETSKOY, V.S.; TORCHILIN, V.P. Use of polyoxyethylene-lipid conjugates as long-circulating carriers for delivery of therapeutic and diagnostic agents. Adv. Drug. Deliv. Rev., v.16, p.311-320, 1995.

UNGER, E.; SHEN, D.; FRITZ, T.; WU, G.L.; KULIK, B.; NEW, T.; MATSUNAGA, T.; RAMASWAMI, R. Liposomes bearing membrane-bound complexes of manganese as magnetic resonance contrast agents. Invest. Radiol., v.29, p.S168-S169, 1994.

VERA, D.R.; WALLACE, A.M.; HOH, C.K. ( ${ }^{99 m}$ TC) $M_{A G}{ }_{3}$ dextran: a receptor binding radiopharmaceutical for sentinel node detection. Nucl. Med. Biol., v.28, p.493-498, 2001. 
VESELOVSKY, A.V., IVANOV, A.S. Strategy of computeraided drug design. Curr. Drug Targets Infect. Disord., v.3, p.33-40, 2003.

WANG, Y.X.; HUSSAIN, S.M.; KRESTIN, G.P. Superparamagnetic iron oxide contrast agents: physicochemical characteristics and applications in MR imaging. Eur. Radiol., v.11, p.2319-2331, 2001.

WERMUTH, C. G. Strategies in the search for new leads compounds or original working hypoteses, In:

The pratice of medicinal chemistry. 3.ed. Oxford: Elsevier, 2008. p.125-143.

WILHELM, A.J.; MIJNHOUT, G.S.; FRANSSEN, E.J.F. Radiopharmaceuticals in sentinel lymph-node detection - an overview. Eur. J. Nucl. Med., v.26, p.S36-S42, 1999.
YOKOYAMA, M.; OKANO, T.; SAKURAI, Y.; SUWA, S.; KATAOKA, K. Introduction of cisplayin into polymeric micelle. J. Control. Release, v.39, p.351-356, 1996.

YOKOYAMA, M.; MIYAUCHI, M.; YAMADA, N.; OKANO, T.; SAKURAI, Y.; KATAOKA, K.; INOUE, S. Characterization and anticancer activity of the micelleforming polymeric anticancer drug adryamicin-conjugated pol(ethylene glycol)-poly(aspartic acid) block copolymer. Cancer Res., v.50, p.1700-1993, 1990.

ZHANG, X.; JACKSON, J.K.; BURT, H.M. Development of amphiphilic diblock copolymers as micellar carriers of taxol. Int. J. Pharm., v.132, p.195-206, 1996.

Received for publication on $31^{\text {st }}$ May 2011 Accepted for publication on $31^{\text {st }}$ October 2011 